\title{
L'architettura ferroviaria e le trasformazioni urbane: il caso di Madrid
}

\author{
Letizia Musaio Somma
}

Abstract

Questa ricerca è incentrata sul ruolo dell'architettura ferroviaria nello sviluppo e nella trasformazione delle città, con particolare attenzione alle città storiche. La costruzione della memoria dei "fatti urbani", studio finalizzato all'elaborazione di nuove proposte progettuali in ambito urbano, riconosce una grande importanza ai fenomeni legati alle trasformazioni ferroviarie che, a partire dall'Ottocento, hanno modificato il volto delle città, imponendo grandi innovazioni in quelli che oggi sono i centri storici delle nostre città e, d'altra parte, gli interventi ferroviari continuano ancora oggi ad essere oggetto di dibattito, poiché rappresentano grandi occasioni di rigenerazione urbana. Si ritiene necessaria la conoscenza della storia dei luoghi, legata allo sviluppo infrastrutturale, per poter definire azioni future concrete, rispettose della vocazione originaria dei luoghi e consapevoli del valore mutato degli edifici ferroviari, da architetture specialistiche per il trasporto ad hub multifunzionali e nuovi spazi pubblici. Caso studio è la città di Madrid che presenta molteplici stazioni ferroviarie con valenze diverse, oggetto di trasformazioni più o meno recenti, città in cui il tessuto urbano è stato modellato, nelle espansioni moderne, dalla presenza della ferrovia. La ricostruzione storica, per mezzo della ricerca di archivio, è affiancata all'analisi delle condizioni attuali e conduce alla ricostruzione grafica delle varie fasi di sviluppo urbano.

Parole chiave

architettura ferroviaria, trasformazioni urbane, città-patrimonio, Madrid, stazioni ferroviarie.

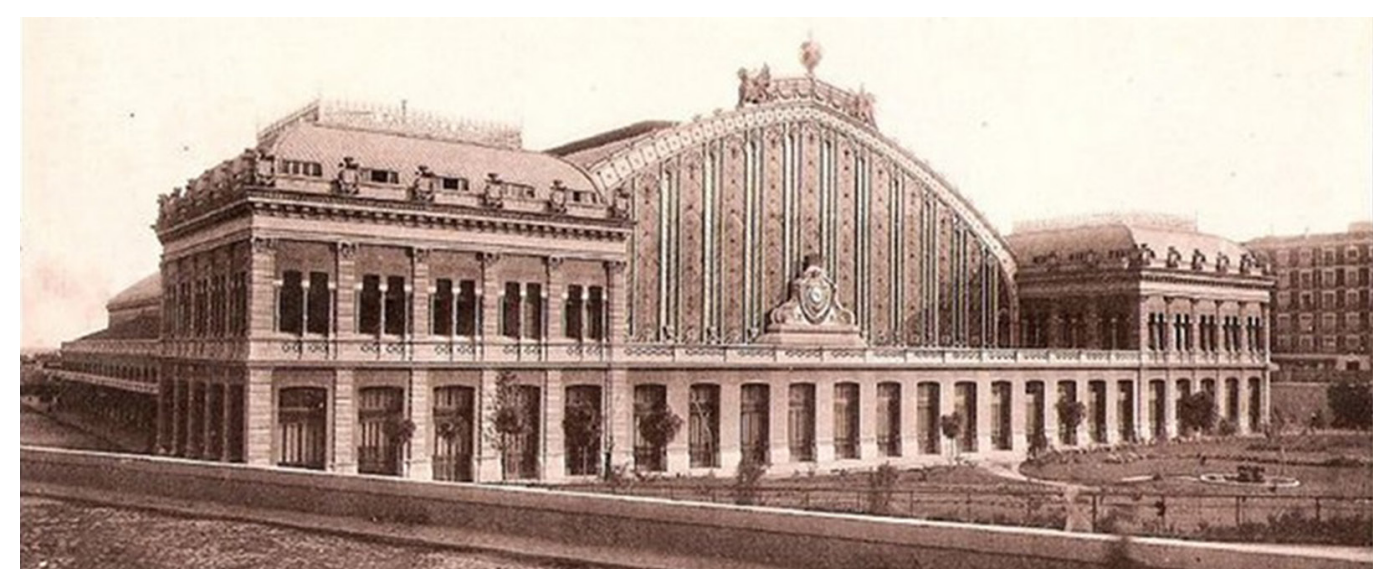




\section{Stazioni ferroviarie nel tessuto urbano}

Gli edifici ferroviari sono architetture emblematiche nello sviluppo urbano, in quanto ne influenzano l'evoluzione e sono influenzati dal contesto. II loro ruolo si è trasformato da quello di edifici destinati al trasporto, a veri e propri luoghi urbani, nuovi poli di aggregazione e di identificazione di una collettività, preservando il loro ruolo centrale nelle città e coinvolgendo un nuovo tipo di trasformazioni urbane.

La ricerca ha origine dall'analisi del ruolo degli edifici ferroviari in epoca contemporanea, in relazione al tessuto urbano. Sin dalla loro comparsa nelle città ottocentesche, le stazioni ferroviarie comportarono grandi innovazioni, portando in città una nuova tipologia architettonica, che si doveva inserire in un contesto storico consolidato. L'introduzione di una nuova tipologia edilizia nel tessuto urbano storico ottocentesco comportò problemi relativi alla scelta della localizzazione di questi edifici e al linguaggio architettonico da adottare per il loro inserimento nel contesto. Parallelamente oggi, in seguito agli interventi di cui sono state oggetto le stazioni ferroviarie, a partire dalle contemporanee necessità di fruizione, conservano il loro ruolo centrale nelle città, portando un nuovo tipo di trasformazioni nella trama urbana. Subiscono interventi di diverso tipo, da quelli che interessano alcune parti dell'edificio, a quelli che ne modificano profondamente il ruolo, ma, nella maggior parte dei casi, conservano la funzione di centralità urbana, non più legata solo ai trasporti, ma si tratta di veri e propri spazi pubblici della città. Le stazioni ferroviarie sono luoghi simbolici nei quali una comunità si identifica e allo stesso tempo costituiscono dei landmarks nel paesaggio urbano.

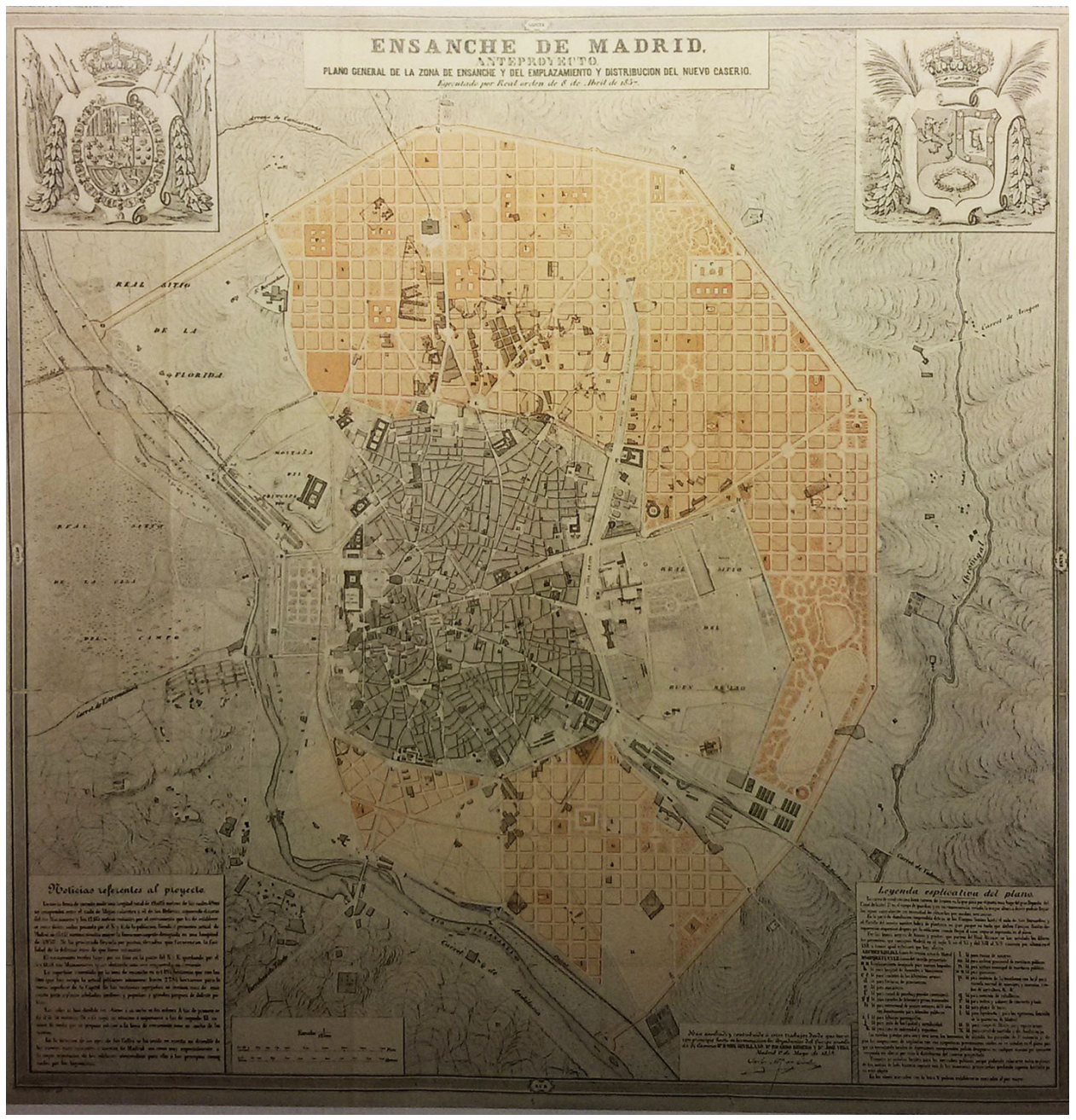


La compresenza di vari elementi propri delle stazioni ferroviarie, alcune possibili trasformazioni contemporanee e lo stretto legame tra gli edifici e il tessuto urbano sono elementi riscontrabili nella città di Madrid, in Spagna [Navascués Palacio 1973]. L'estensione della città sul territorio e la storia del suo sviluppo urbano hanno determinato la costruzione di diverse stazioni ferroviarie. Una rete complessa di trasporti attraversa l'intera città di Madrid, contribuendo alla formazione di importanti nodi intermodali. Proprio lo stretto legame tra queste architetture e la città è oggetto di un'analisi urbana approfondita, alla luce della quale è possibile comprendere il ruolo di percorsi urbani e accessi in relazione con le stazioni ferroviarie ed individuare le linee guida per gli interventi contemporanei.

L'analisi delle relazioni tra gli edifici ferroviari ed il tessuto urbano della città di Madrid è interessante per comprendere la formazione e gli sviluppi della città. Queste architetture hanno sempre avuto un ruolo importante individuando le direzioni di sviluppo urbano a partire dalla città Ottocentesca e, ancora oggi, sono riconoscibili le tracce della loro presenza, anche quando gli edifici ferroviari sono andati perduti. Essi conservano un interesse architettonico, storico ed urbano e la conservazione della loro memoria è resa possibile dalla ricostruzione grafica, testimonianza dell'architettura.

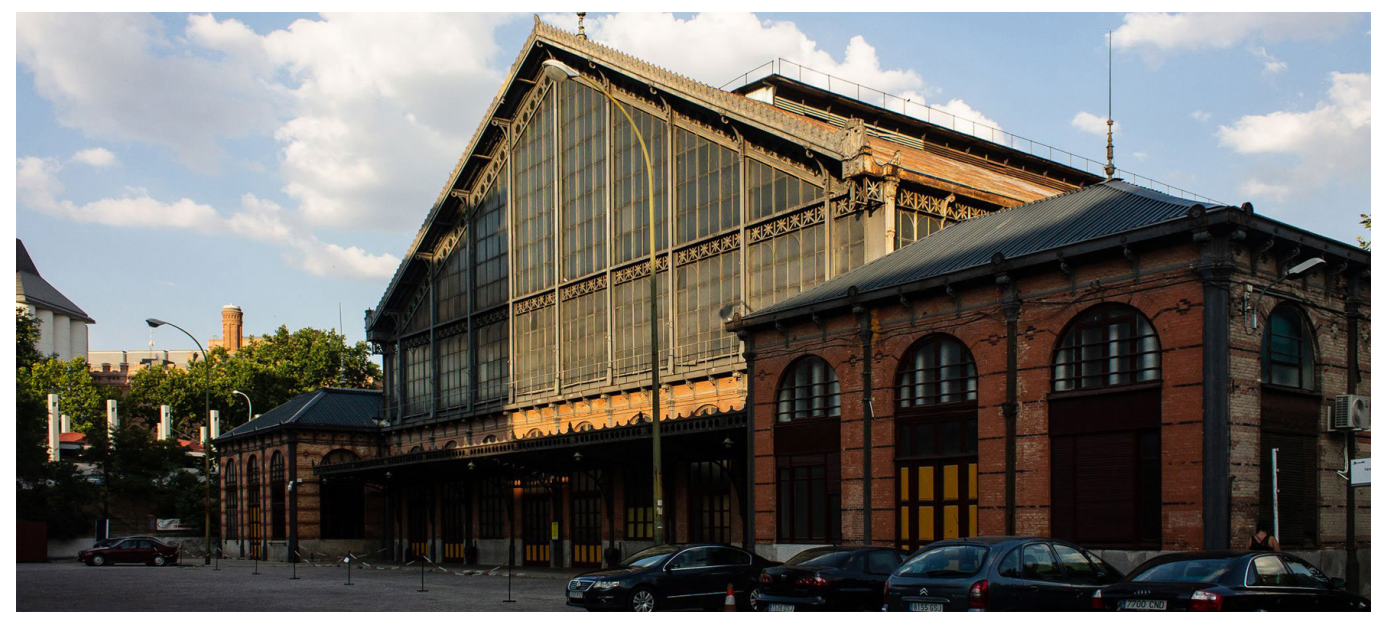

\section{Ricostruzione bibliografica per la ricostruzione grafica}

Alcuni ricercatori hanno analizzato il tema degli edifici ferroviari in alcune città spagnole, tra cui la capitale Madrid, ma l'intento di questo studio è quello di evidenziare gli aspetti di continuità tra il layout urbano e l'inclusione degli edifici ferroviari, architetture paragonabili alle antiche porte urbane per il loro ruolo in città [Aguilar Civera 1988].

Riferimenti bibliografici principali sono le opere di Pedro Navascués Palacio che analizza l'architettura spagnola del XIX secolo, concentrandosi sugli edifici ferroviari. Nell'excursus storico a partire dall'Ottocento, tratta anche il tema delle porte della città di Madrid e dell'ampliamento urbano dell'Ensanche [Navascués Palacio 1973] (fig. I) della metà del XIX secolo, fino a dedicare un capitolo specifico all'architettura del ferro, soffermandosi su tre stazioni ferroviarie di Madrid: Atocha, Delicias e Norte.

Fondamentale anche il contributo di Inmaculada Aguilar Civera, che analizza l'architettura degli edifici ferroviari, ponendoli in relazione con il contesto urbano in cui si inseriscono. Approfondisce, inoltre, gli aspetti del rapporto tra le stazioni e la città e della tipologia architettonica di questi edifici, analizzando le diverse soluzioni planimetriche adottate in Spagna e si sofferma sulla città di Madrid [Aguilar Civera 1980]. 


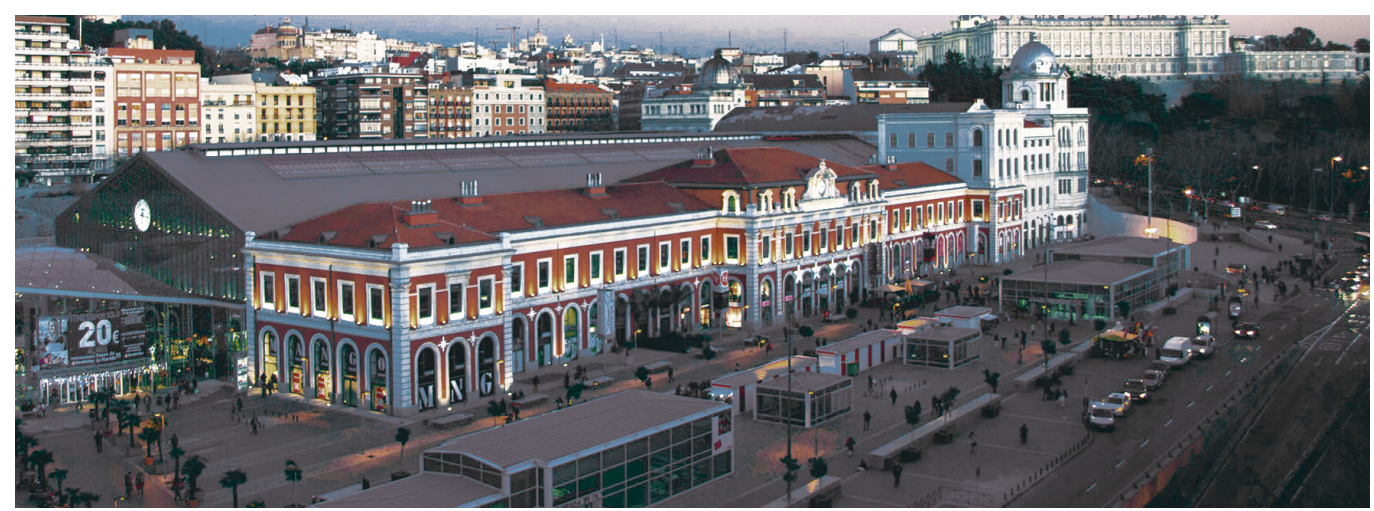

L'analisi a diverse scale, da quella territoriale a quella urbana, fino all'analisi architettonica è stata condotta a partire dalla ricerca bibliografica e d'archivio svolta in loco nei principali archivi della città di Madrid, quello della Escuela Técnica Superior de Arquitectura di Madrid, del Colegio Oficial de Arquitectos di Madrid, dell'Archivo Histórico Ferroviario di Madrid e della Casa de Velázquez di Madrid.

II caso della città di Madrid racchiude in sé un ampio campionario delle tipologie di trasformazioni subite dagli edifici ferroviari, in quanto le quattro stazioni principali, ancora oggi esistenti, hanno assunto ognuna un ruolo diverso in epoca contemporanea. La stazione ferroviaria di Delicias (fig. 2) è stata trasformata in Museo ferroviario, mantenendo un uso coerente con la sua precedente funzione legata ai trasporti. Quella del Norte (fig. 3), invece, è stata trasformata in centro commerciale, con un uso sovrapposto al carattere proprio dell'edificio. La stazione di Atocha (fig. 4) ha conservato la sua funzione, ma è stata ampliata

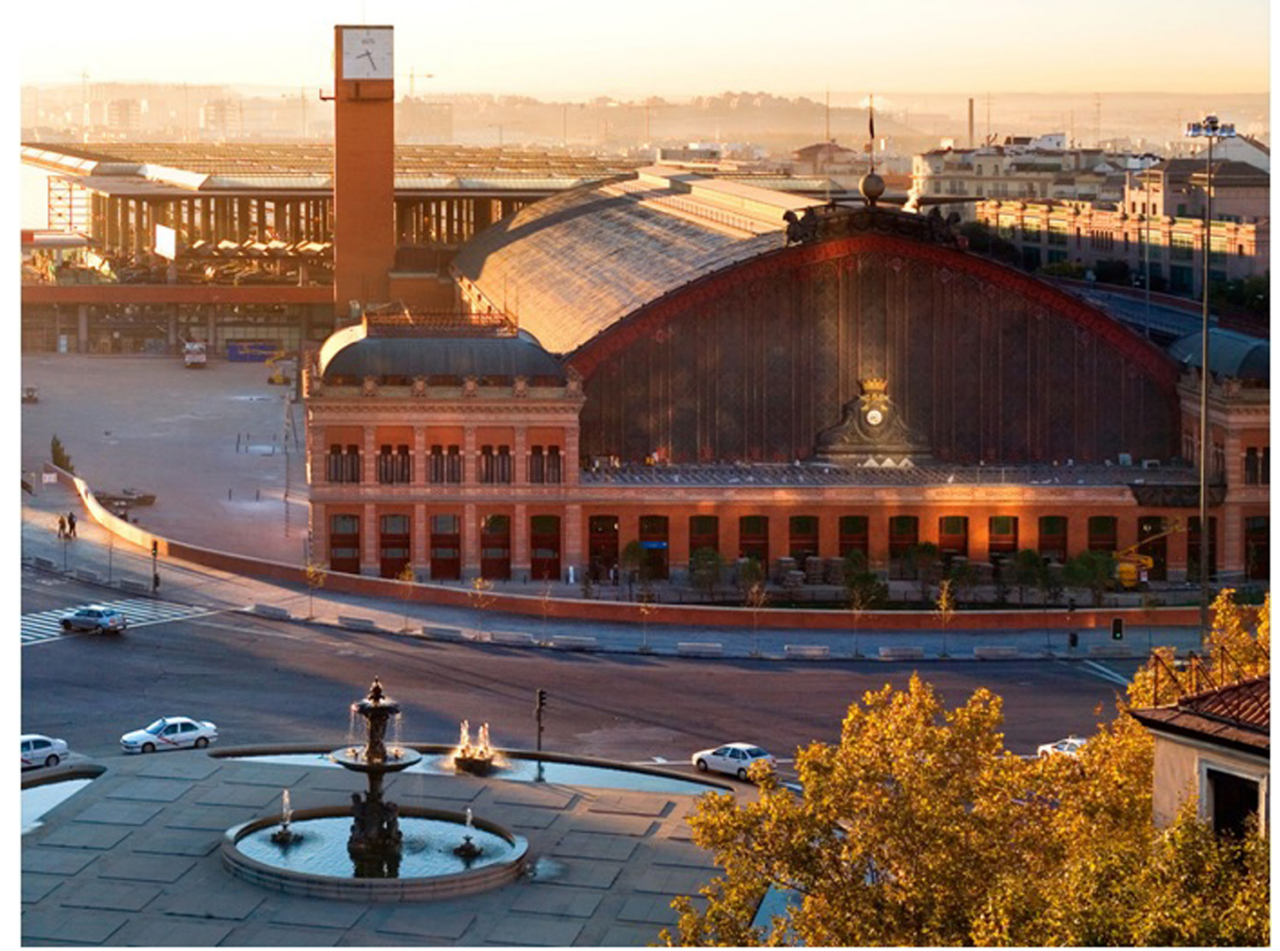


ed adattata alle esigenze dei trasporti ad alta velocità. La stazione ferroviaria di Chamartín ha subito un intervento in epoca contemporanea di interramento dei binari e conseguente nuova fruizione dell'area liberatasi [González Yancí 1977].

Le prime stazioni costruite nell'Ottocento furono edificate lungo una corona circolare intorno al centro storico. Facevano capo a linee diverse che si dipartivano dalla capitale e per questa loro disposizione furono creati i primi collegamenti tra le stazioni urbane (figg. 5, 6). Gli edifici si attestano lungo quello che era il tracciato dell'antica cinta muraria che racchiudeva il nucleo abitato della città di Madrid. Nelle mura storiche si aprivano porte di accesso in corrispondenza dei percorsi provenienti dai territori limitrofi ed è proprio in questi luoghi che spesso sono state edificate le stazioni ferroviarie. L'analisi si concentra su questo aspetto, evidenziando i caratteri di continuità tra le antiche porte urbane e gli edifici ferroviari che, per diversi aspetti, costituiscono le moderne porte urbane (fig. 7).
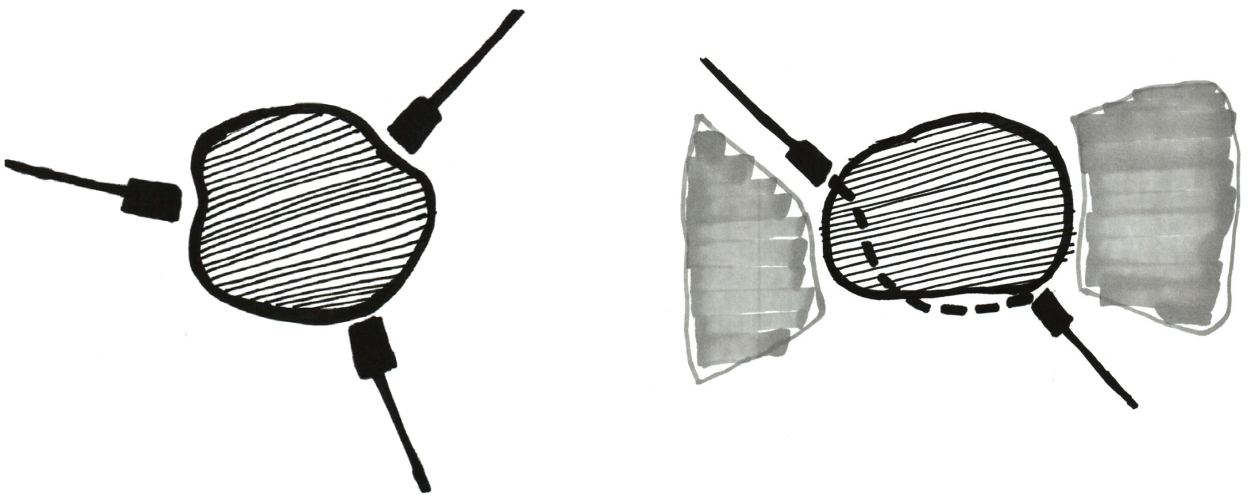

\section{La memoria come base per i nuovi interventi}

L'analisi a diverse scale, da quella territoriale a quella urbana, fino all'analisi architettonica è stata effettuata attraverso la raccolta e il confronto tra varie mappe storiche della rete ferroviaria appartenenti a periodi diversi. Lo studio delle mappe urbane di alcune città spagnole e in particolare di Madrid ha permesso di ricostruire l'evoluzione storica di un organismo urbano, con particolare attenzione alla rete ferroviaria [González Yancí 1977] (fig. 8).

Lo studio del rapporto tra stazioni ferroviarie e città storiche parte dalla necessità di conoscere l'evoluzione di questi edifici, per identificare le linee guida per interventi contemporanei. Partendo dall'analisi delle relazioni ferrovia-contesto urbano in alcune città storiche, si è proceduto con la ricostruzione grafica delle fasi di sviluppo urbano in relazione con gli edifici ferroviari, evidenziando la continuità esistente tra percorsi storici, antiche porte urbane verso la città e posizione e conformazione degli edifici ferroviari rispetto al tessuto urbano. L'analisi di questi elementi ha permesso di identificare le linee guida per la progettazione di interventi futuri, da adottare in contesti storici stratificati.

L'analisi, condotta con l'ausilio della rappresentazione grafica, è tesa ad evidenziare il rapporto di reciproca influenza tra gli edifici ferroviari e il contesto urbano. È stato posto in evidenza, in particolar modo, lo stretto legame tra i percorsi territoriali ed urbani preesistenti e l'innesto delle stazioni in luoghi strategici nel tessuto urbano. Questa connessione è risultata ancor più netta dai tratti comuni dei luoghi dove si ergevano le antiche porte urbane; in molti casi gli stessi siti in cui poi sono sorti gli edifici ferroviari, definibili 'moderne porte urbane'. Ancora una volta attraverso un'indagine grafica è stato possibile ricostruire il processo di trasformazione che ha interessato alcune di queste architetture, interessante, 
in particolar modo, per quelle che oggi non esistono più, scomparse nel corso della storia. Questo rappresenta un contributo fondamentale nella ricostruzione di un patrimonio, altrimenti perduto, e ne consente la conoscenza e la divulgazione.

Per comprenderne le architetture ed il loro rapporto con la città, si è partiti dalla ricerca bibliografica e d'archivio finalizzata alla ricostruzione grafica degli edifici non più esistenti. Gli elaborati prodotti costituiscono testimonianza del patrimonio culturale di un luogo, le cui tracce non sono più visibili. Parallelamente si è analizzato il tessuto urbano, attraverso le carte storiche, fino all'elaborazione di disegni che evidenziano le trasformazioni osservate nel tessuto urbano nei dintorni degli edifici ferroviari, ponendo particolare attenzione sui percorsi e gli accessi urbani (fig. 9).

\section{Dalle stazioni storiche alle trasformazioni contemporanee}

Tra i principali risultati raggiunti vi è la ricostruzione grafica delle fasi degli edifici ferroviari in relazione alla trama urbana; la rappresentazione delle varie fasi di sviluppo costituisce anche una testimonianza degli edifici non più esistenti ed è finalizzata alla conoscenza ed alla diffusione della memoria del patrimonio culturale, come base per interventi contemporanei in contesti storici stratificati.

Fig. 7. Ricostruzione grafica della città di Madrid e del sistema ferroviario in epoca contemporanea.

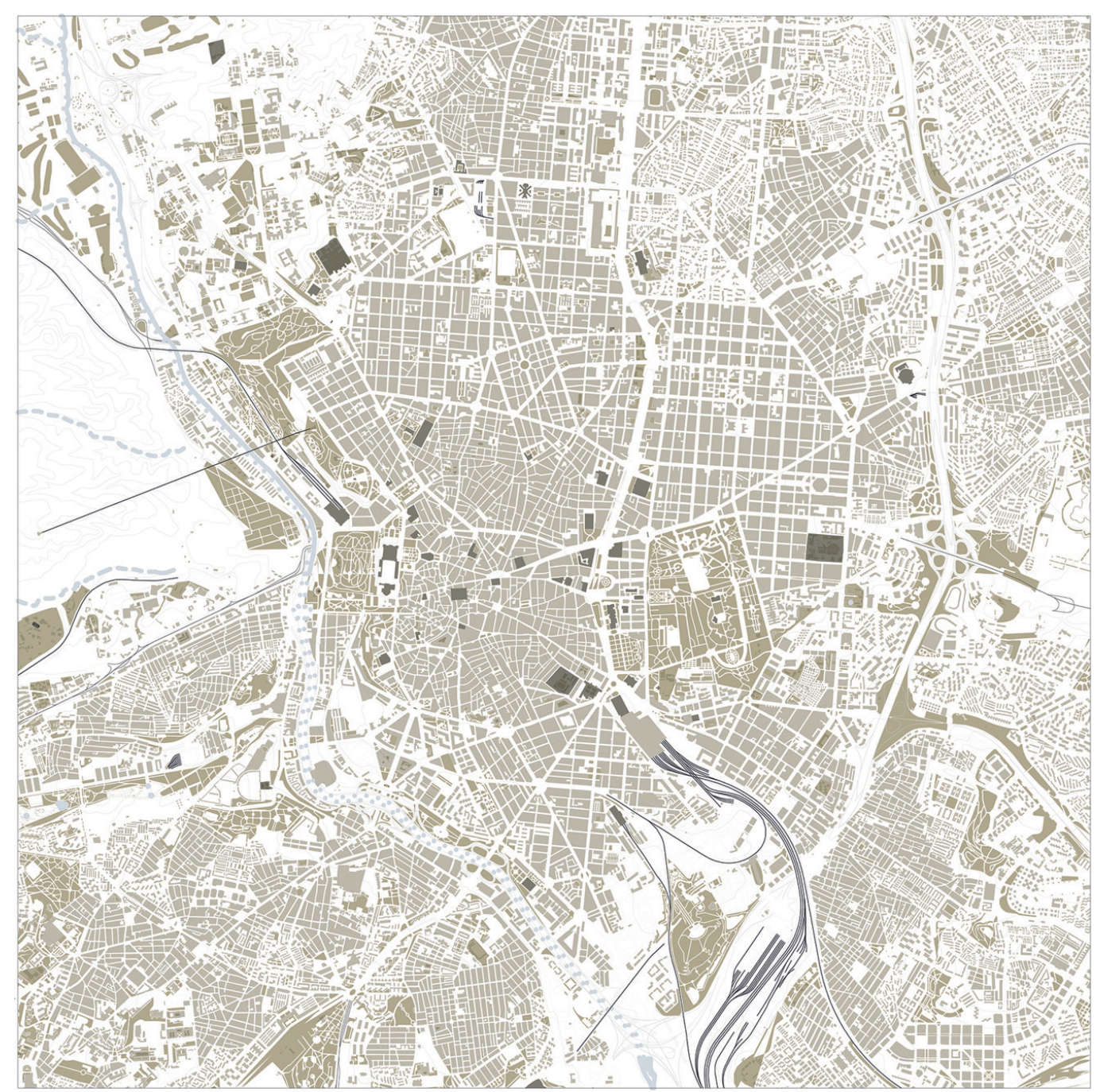




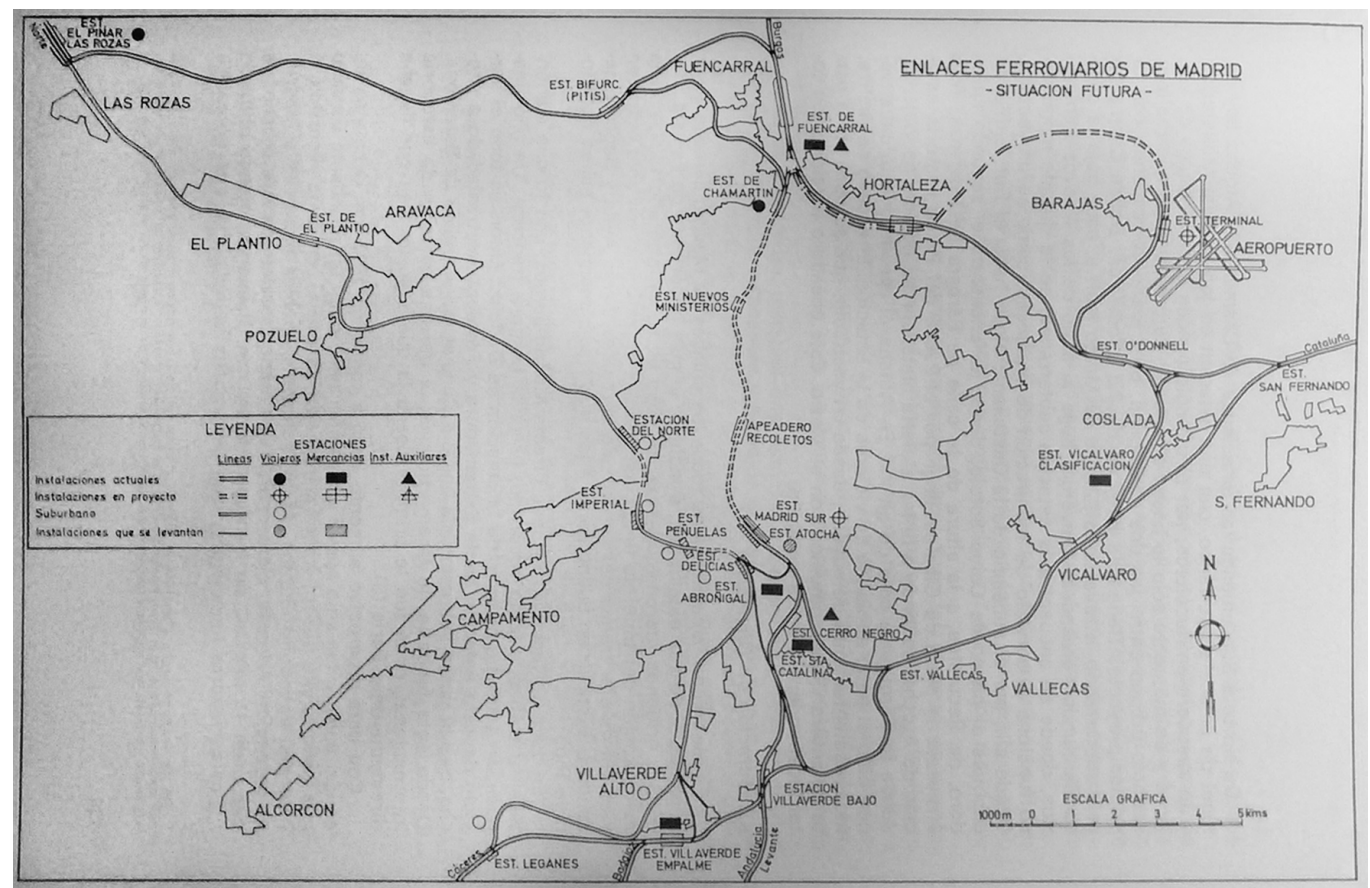

L'obiettivo è lo studio delle azioni progettuali che coinvolgono gli edifici ferroviari nella loro evoluzione storica, con l'obiettivo di identificare le linee guida di intervento in contesti storici. La ricostruzione storica delle aree urbane per mezzo del rilievo e del progetto consente la conoscenza e la valorizzazione dei luoghi per mezzo della rappresentazione dell'architettura esistente e delle nuove proposte.

Sono stati analizzati disegni storici, progetti presentati in concorsi, rilievi grafici che coprono periodi diversi e progetti di proposte future al fine di averne una conoscenza critica.

L'approccio multidisciplinare tra architettura e pianificazione urbana è la base per l'identificazione di buone pratiche di intervento in un contesto storico stratificato che richiede interventi contemporanei. La ricostruzione storica dei processi urbani relativi al campo delle infrastrutture, intesa in prospettiva architettonica, evidenzia gli elementi di continuità e rottura nella storia della trasformazione dei luoghi.

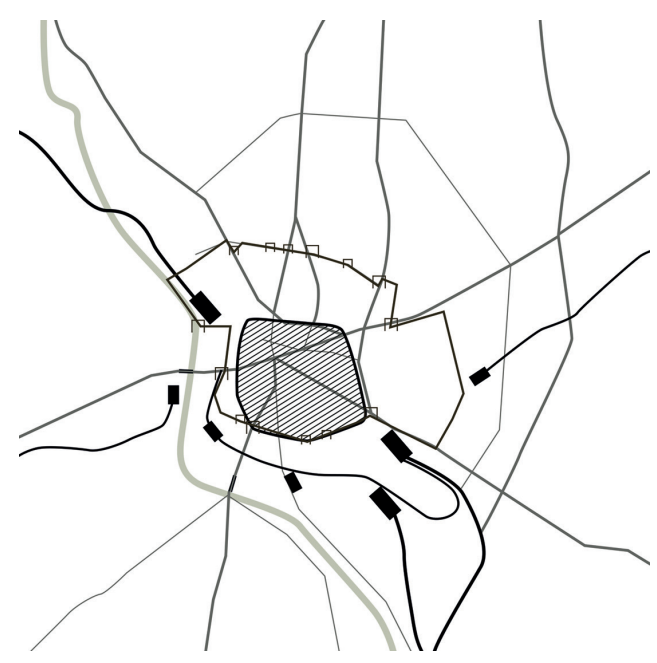


La ricostruzione, attraverso il disegno, degli edifici ferroviari nelle varie fasi di sviluppo e la rappresentazione di quelli non più esistenti costituisce un patrimonio importante da utilizzare non solo a fini conoscitivi, ma anche come punto di partenza per la progettazione di nuovi interventi. Gli edifici ferroviari rappresentano luoghi emblematici del passaggio tra tradizione e innovazione, trovandosi a cavallo tra l'Ottocento e l'epoca contemporanea, nella gran parte dei casi persistendo alle trasformazioni e adattandosi alle nuove esigenze. Non hanno solo un ruolo legato alla loro funzione infrastrutturale, ma costituiscono parte integrante del patrimonio architettonico, urbano e culturale di una società, che in essi si identifica, in quanto simboli di un luogo. Per queste ragioni non sono solo architetture da conservare e preservare, ma da conoscere e fruire. Attraverso l'analisi critica e la ricostruzione storica, si può procedere all'ideazione delle trasformazioni future, sulla base di un ragionamento critico, operato a partire dalla conoscenza della storia dei luoghi. Le linee guida individuate a partire da questo tipo di analisi, possono essere adottate per operare in altri contesti simili dal punto di vista del valore storico-culturale dei luoghi.

\section{Riferimenti bibliografici}

Aguilar Civera Inmaculada (1980). Las estaciones ferroviarias de Madrid: su arquitectura e incidencia en el desarrollo de la ciudad. Madrid: Colegio Oficial de Arquitectos de Madrid.

Aguilar Civera Inmaculada (1988). La estación de ferrocarril, puerta de la ciudad. Valencia: Generalitat Valenciana, Consellería de Cultura, Educación i Ciència.

González Yancí Maria Pilar (1977). Los accesos ferroviarios a Madrid: su impacto en la geografía urbana de la ciudad. Madrid: Instituto de Estudios Madrileños.

Navascués Palacio Pedro (1973). Arquitectura y arquitectos madrileños del siglo XIX. Madrid: Instituto de Estudios Madrileños.

Navascués Palacio Pedro (2007). Arquitectura e ingeniería del hierro en España, ( 8 | 4-1 936). Madrid: Fundación Iberdrola.

\footnotetext{
Autore

Letizia Musaio Somma, Università degli Studi della Basilicata, letiziamusaiosomma@gmail.com

Per citare questo capitolo: Musaio Somma Letizia (2020). L'architettura ferroviaria e le trasformazioni urbane: il caso di Madrid/Railway Architecture and Urban Transformation: the Case of Madrid. In Arena A., Arena M., Brandolino R.G., Colistra D., Ginex G., Mediati D., Nucifora S., Raffa P. (a cura di). Connettere. Un disegno per annodare e tessere. Atti del $42^{\circ}$ Convegno Internazionale dei Docenti delle Discipline della Rappresentazionel Connecting. Drawing for weaving relationships. Proceedings of the 42th International Conference of Representation Disciplines Teachers. Milano: FrancoAngeli, pp. 2477-2492.
} 


\title{
Railway Architecture and Urban Transformation: the Case of Madrid
}

\author{
Letizia Musaio Somma
}

\section{Abstract}

This research focuses on the role of railway architecture in the development and transformation of cities, with particular attention to historic cities. The construction of the memory of "urban facts", a study aimed to elaborate new design proposals in the urban field, recognizes a great importance to the phenomena related to railway transformations which have changed the face of cities, starting from the nineteenth century, imposing great innovations in the historic centres of our cities and, on the other hand, railway interventions continue to be subject of debate today, since they represent great opportunities for urban regeneration. The knowledge of the history of places, linked to infrastructure development, is considered necessary in order to define concrete future actions, respectful of the original vocation of places and aware of the changed value of railway buildings, from architectures for transport to multifunctional hubs and new public spaces. Case study is the city of Madrid which has multiple railway stations with different values, affected by recent transformations. Madrid is a city where the urban fabric was shaped, in modern expansions, by the presence of the railway. The historical reconstruction, by means of archive research, is accompanied by the analysis of current conditions and leads to the graphic reconstruction of the various phases of urban development.

Keywords

railway architecture, urban transformations, heritage city, Madrid, railway stations.

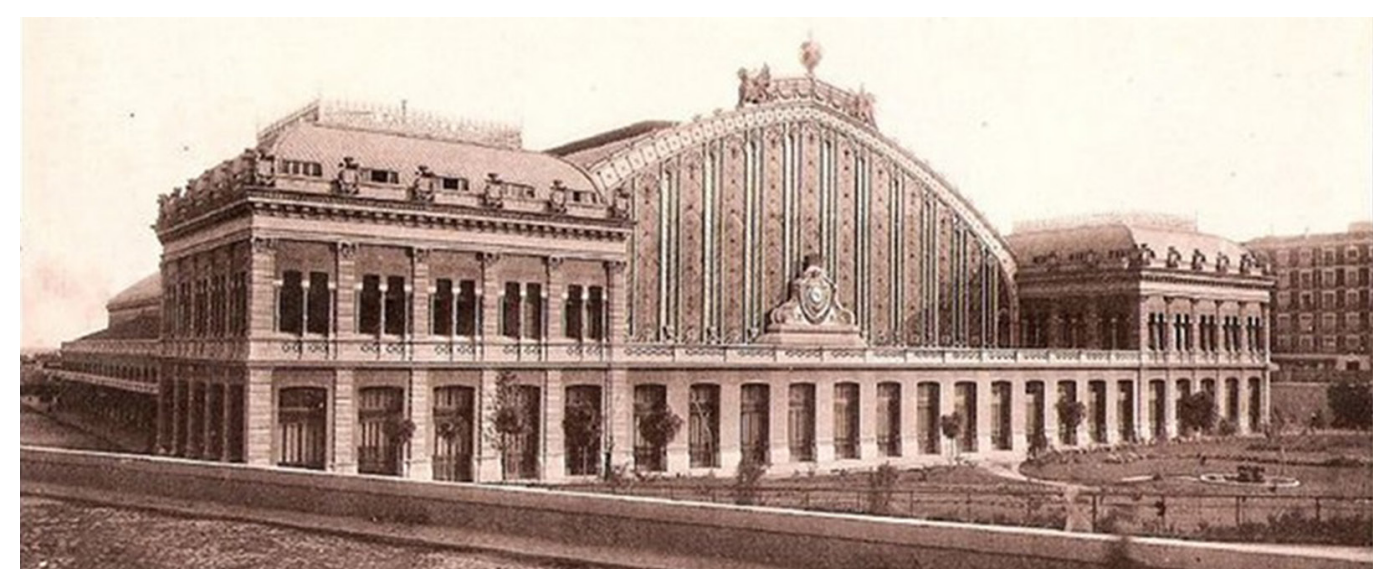




\section{Railway stations in the urban fabric}

Railway buildings are emblematic architectures in urban development, as they influence its evolution and are influenced by the context. Their role has been transformed from being buildings linked to transport, to urban spaces, new poles of aggregation and identification of a community, preserving their central role in cities and involving a new type of urban transformations.

The research arises from the analysis of the role of railway buildings in contemporary times, related to the urban context. Since their appearance in nineteenth-century cities, the railway stations involved major innovations, bringing a new architectural typology to the city, which had to be inserted into a consolidated historical context. At the same time today, following the interventions they have undergone, starting from the contemporary needs, the station buildings retain their central role in the cities, bringing a new type of transformation into the urban plot. They undergo different types of interventions, from those that affect some parts of the building to those that deeply modify their role, but, in most cases, retain the function of urban centrality, no longer linked to transport only, but they are urban 'places'. Railway stations are symbolic places in which a community can identify itself and at the same time represent landmarks in the urban landscape.

The coexistence of various elements typical of railway stations, some possible contemporary transformations and the close link between the buildings and the urban fabric are elements that can be found in the city of Madrid, in Spain [Navascués Palacio 1973]. The

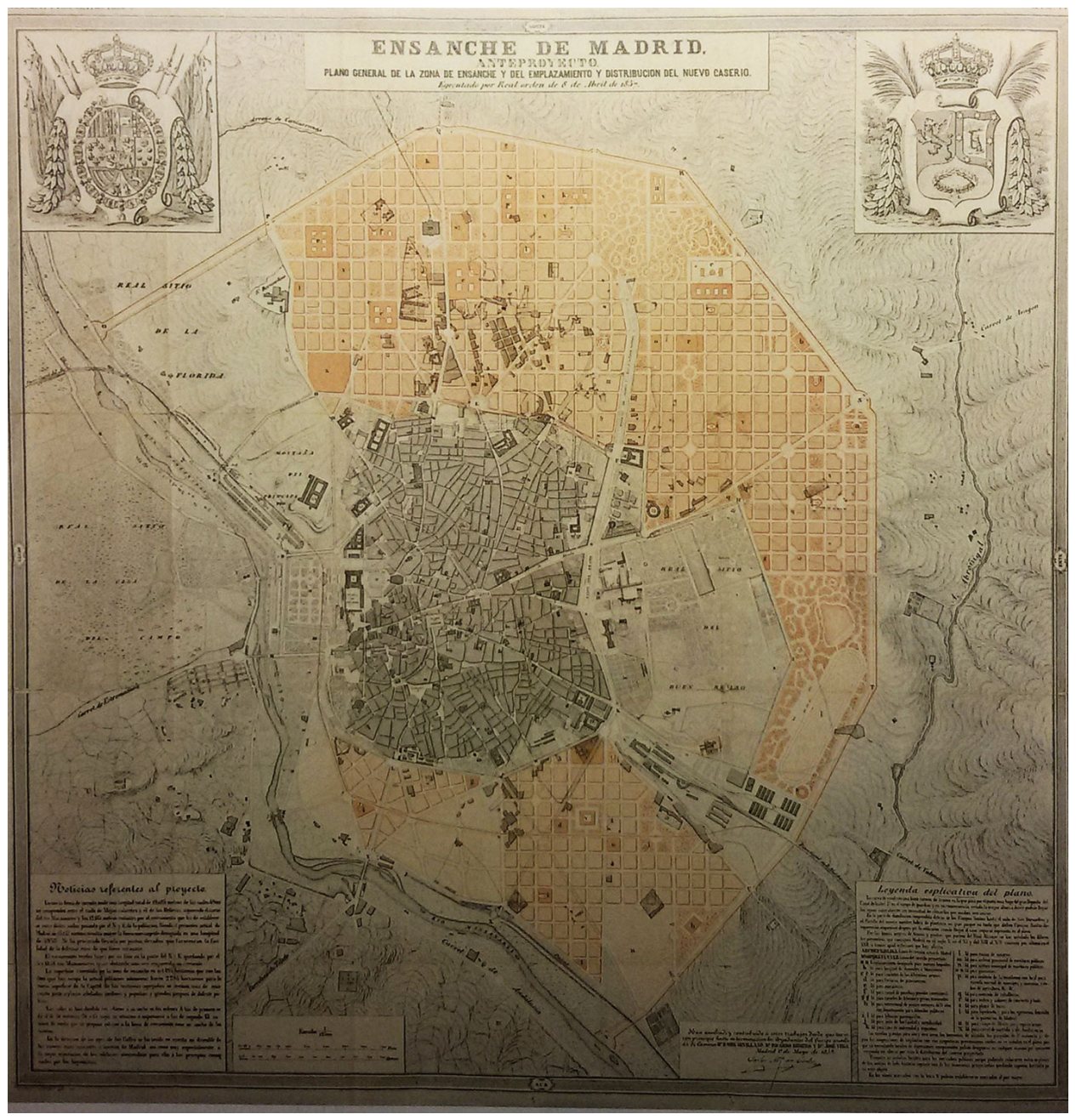


extension of the city over the territory and the history of its urban development led to the construction of several railway stations. A complex transport network runs through the entire city of Madrid, forming important intermodal hubs. The close link between these architectures and the city is the subject of an in-depth urban analysis, finalized to understand the role of urban routes and gates in relation to the railway stations and to identify the guidelines for contemporary interventions.

The analysis of the existing relationships between the railway buildings and the urban fabric of Madrid is interesting to understand the developments of the city. These architectures have played an important role in identifying the directions of development starting from the nineteenth-century city and, even today, traces of their presence can be indentified even when the railway buildings have been destroyed. Those buildings still retain an architectural, historical and urban interest and the preservation of their memory is made possible by graphic reconstruction, a testimony of the architecture.

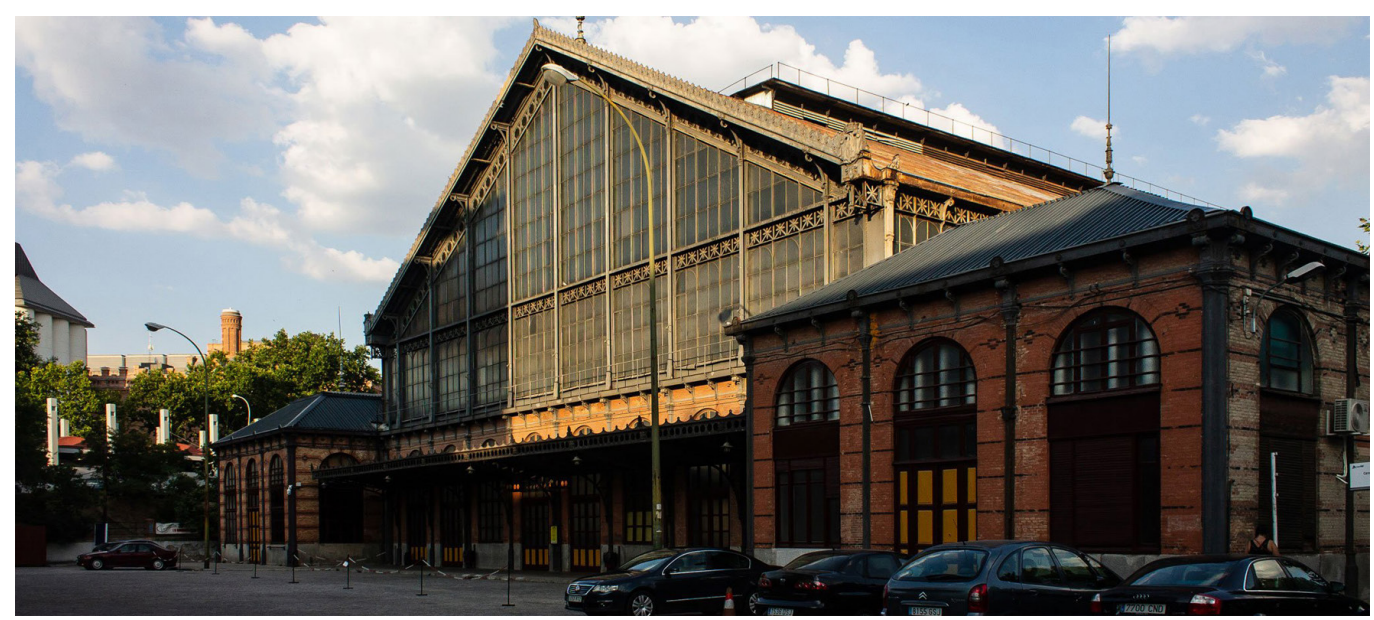

\section{Bibliographical reconstruction for graphic reconstruction}

Some researchers have analyzed the theme of railway buildings in some Spanish cities, including the capital Madrid, but the intent of this study is to highlight the aspects of continuity between the urban layout and the inclusion of railway buildings, architecture comparable to the ancient urban gates for their role in the city [Aguilar Civera 1988].

The main bibliographical references are the works of Pedro Navascués Palacio, which analyzes nineteenth-century Spanish architecture, focusing on railway buildings. In the historical excursus from the nineteenth century, it also deals with the theme of the urban gates of Madrid and the Ensanche [Navascués Palacio 1973] (fig. I) of the city of the mid-nineteenth century, and dedicates a specific chapter to the architecture of iron, focusing on three railway stations in Madrid: Atocha, Delicias and Norte.

The contribution of Inmaculada Aguilar Civera, who analyzes the architecture of railway buildings, is also fundamental, placing them in relation with the urban context in which they stand. Furthermore, she explores the aspects of the relationship between the stations and the city and architectural typology of these buildings, analyzing the different planimetric solutions adopted in Spain and in particular in Madrid [Aguilar Civera 1980]. 


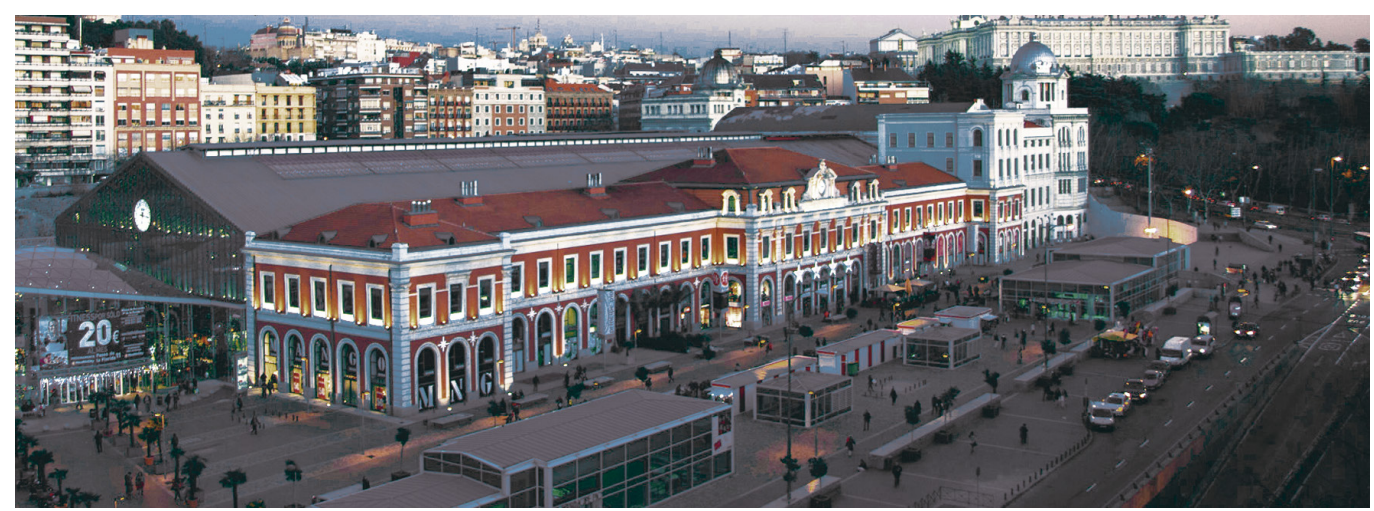

The analysis on different scales, from the territorial to the urban one, up to the architectural analysis was conducted starting from the bibliographic and archive research carried out on site in the main archives of the city of Madrid, that of the Escuela Técnica Superior de Arquitectura of Madrid, the Colegio Oficial de Arquitectos de Madrid, the Archivo Histórico Ferroviario of Madrid and the Casa de Velázquez in Madrid.

The city of Madrid offers different types of transformations operated on railway buildings, as the four main stations, still existing today, but have a different role in the contemporary era. The Delicias railway station (fig. 2) has been transformed into a railway museum, maintaining a use related to its former transport function. The Norte station (fig. 3), on the other hand, has been transformed into a shopping center, with a use superimposed on the character of the building itself. The Atocha station (fig. 4 ) has retained its function but has been expanded and adapted to the needs of high-speed transport. The train station in Chamartín has

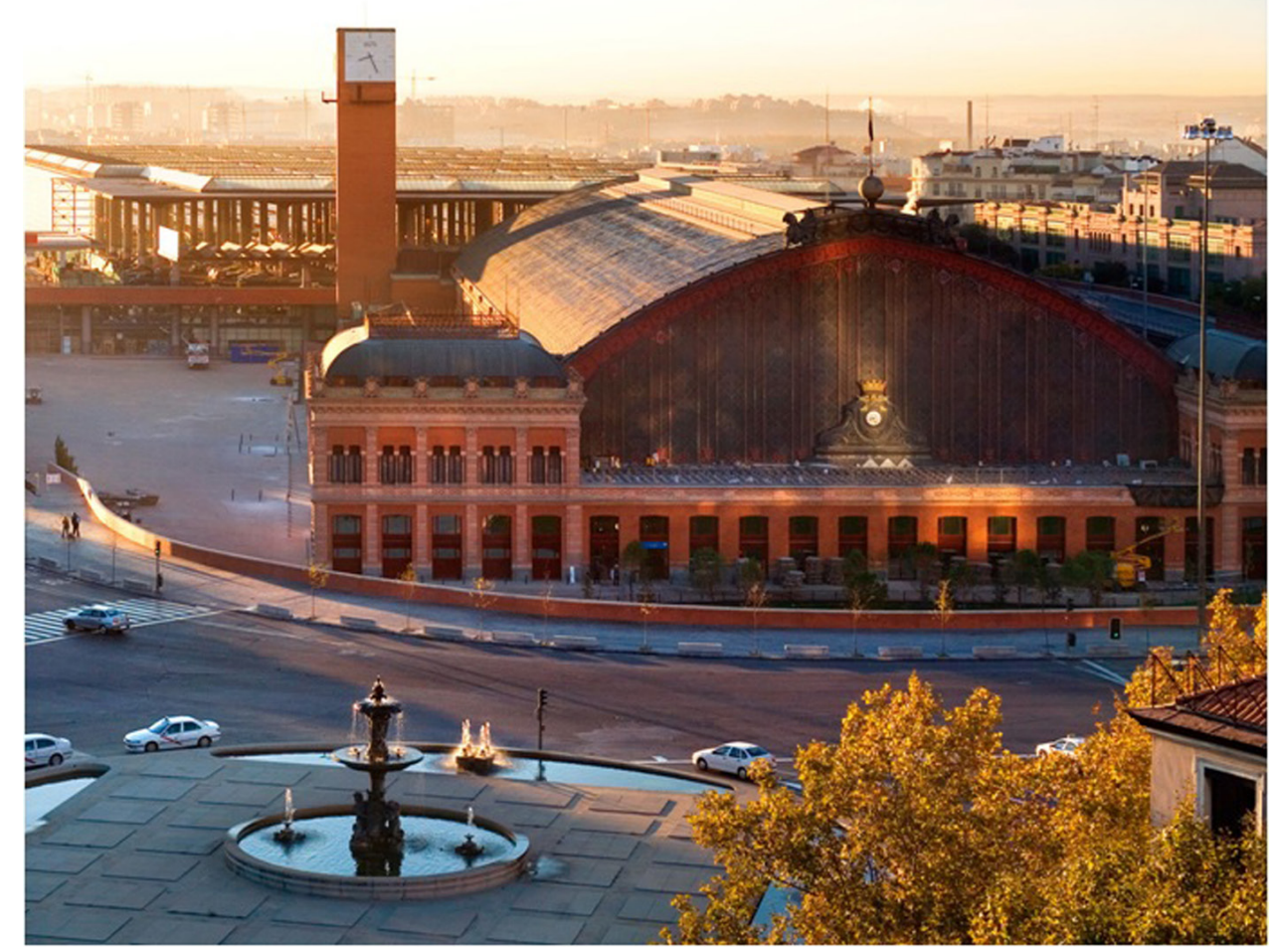


Fig. 5. Scheme of the relationship between railway buildings and the urban fabric: ring and terminal railway stations.

Fig. 6. Scheme of the relationship between railway buildings and the urban fabric: terminal railway connection. undergone an intervention in the contemporary era of burying the tracks and consequent new use of the area freed up [González Yancí 1977].

First stations were built in the nineteenth century along a circular crown around the historic center.They were the head points of different lines that departed from the capital and for this arrangement the first connections between the urban stations were created (figg. 5,6). The buildings stand along what was once the layout of the ancient city wall that enclosed the inhabited center of the city of Madrid. In the historical walls, access doors opened in correspondence with the paths coming from the neighboring territories and it is precisely in these places that the railway stations were often built. The analysis focuses on this aspect, highlighting the characteristics of continuity between the ancient urban gates and the railway buildings which, in different aspects, constitute the modern urban gates (fig. 7).
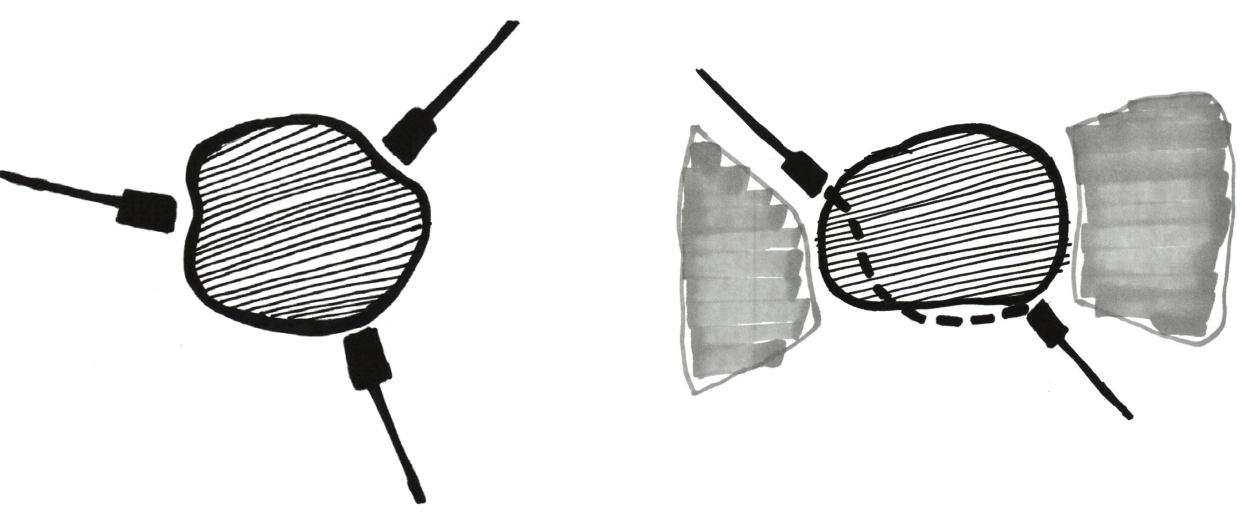

\section{Memory as base for new interventions}

The analysis by different scales, from the territorial to the urban, up to the architectural analysis was carried out through the collection and comparison among various historical maps of the railway network belonging to different periods. The study of the urban maps of some Spanish cities and in particular of Madrid, has allowed to reconstruct the historical evolution of an urban organism, with particular attention to the railway network [González Yancí 1977] (fig. 8).

The study of the relationship between railway stations and historical cities starts from the need to know the evolution of these buildings, to identify guidelines for contemporary intervention. Starting from the analysis of the railway-context relations in some historical cities, we proceeded to the graphic reconstruction of the urban development phases in relation to the railway building, highlighting the continuity existing between historical routes, ancient urban gates to the city and position and conformation of the railway buildings compared to the urban fabric. The analysis of these elements made it possible to identify guidelines for planning future interventions, to be adopted in stratified historical contexts. The analysis, carried out with the aid of the graphic representation, is aimed to highlight the relationship of mutual influence between the railway buildings and the urban context. The close link between the pre-existing territorial and urban paths and the grafting of the stations in strategic places within the urban fabric was highlighted. This connection was even more evident from the common features of the places where the ancient city gates were built; in many cases the same sites where the railway buildings stand, may be defined as 'modern urban gates'. Through a graphic survey it was possible to reconstruct the transfor- 
mation process that has affected some of these architectures. This represents a fundamental contribution in the reconstruction of a heritage, otherwise lost, and allows its knowledge and dissemination.

In order to understand architecture and its relationship with the city, we started from the bibliographic and archival research aimed at the graphic reconstruction of the buildings that no longer exist. The works produced testify the cultural heritage of a place, whose traces are no longer visible. At the same time, the urban fabric was analyzed, through historical maps, up to the elaboration of drawings that highlight the transformations observed in the urban fabric around the railway buildings, paying attention to urban routes and accesses (fig. 9).

\section{From Historical stations to contemporary transformations}

One of the main achievements is the graphic reconstruction of the initial stages of railway buildings, related to the urban plot, the representation of the various stages of development constitutes a testimony of buildings no longer existing and is aimed to the knowledge and dissemination of the memory of the cultural heritage, as basis for contemporary interventions in stratified historical contexts.
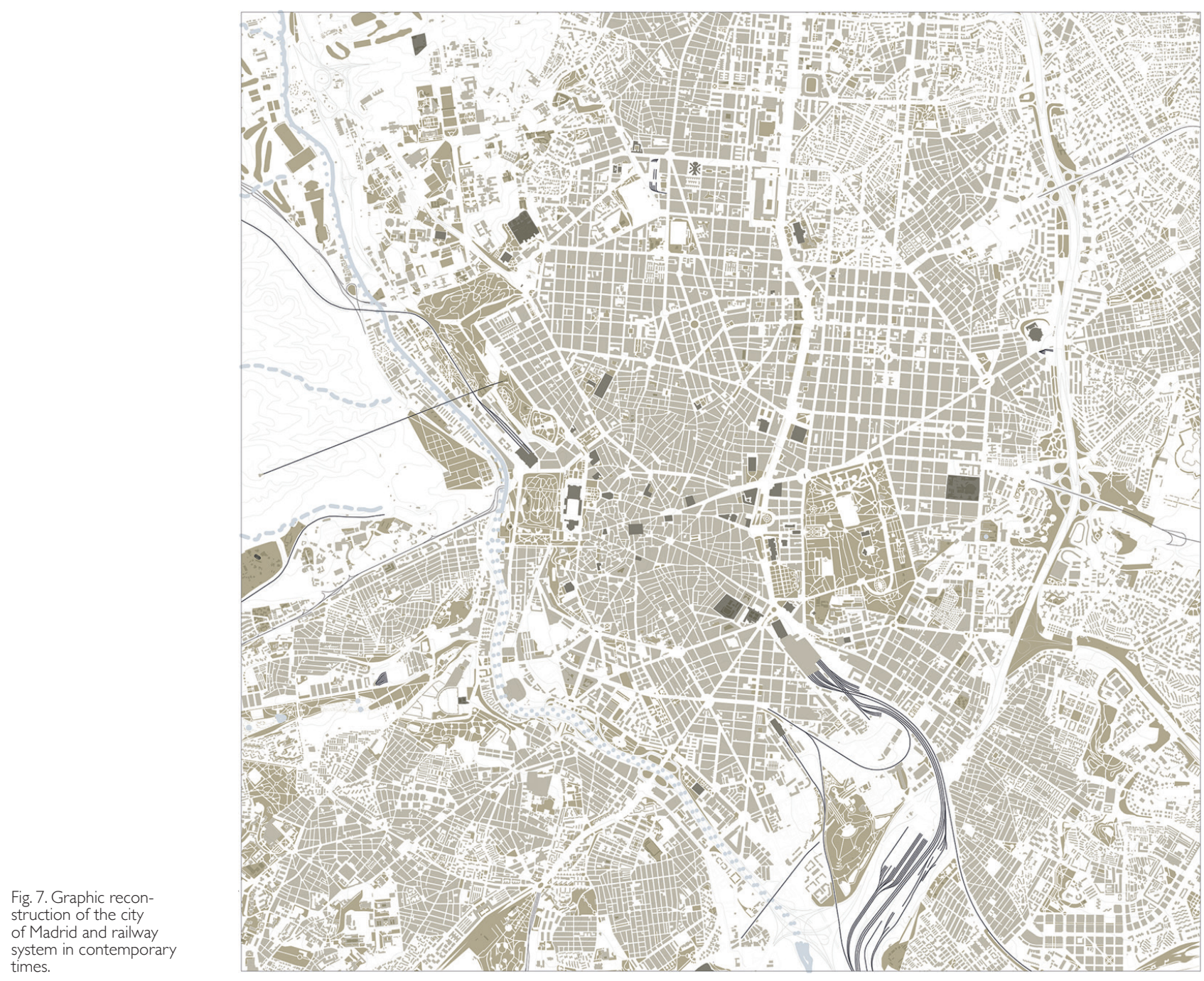


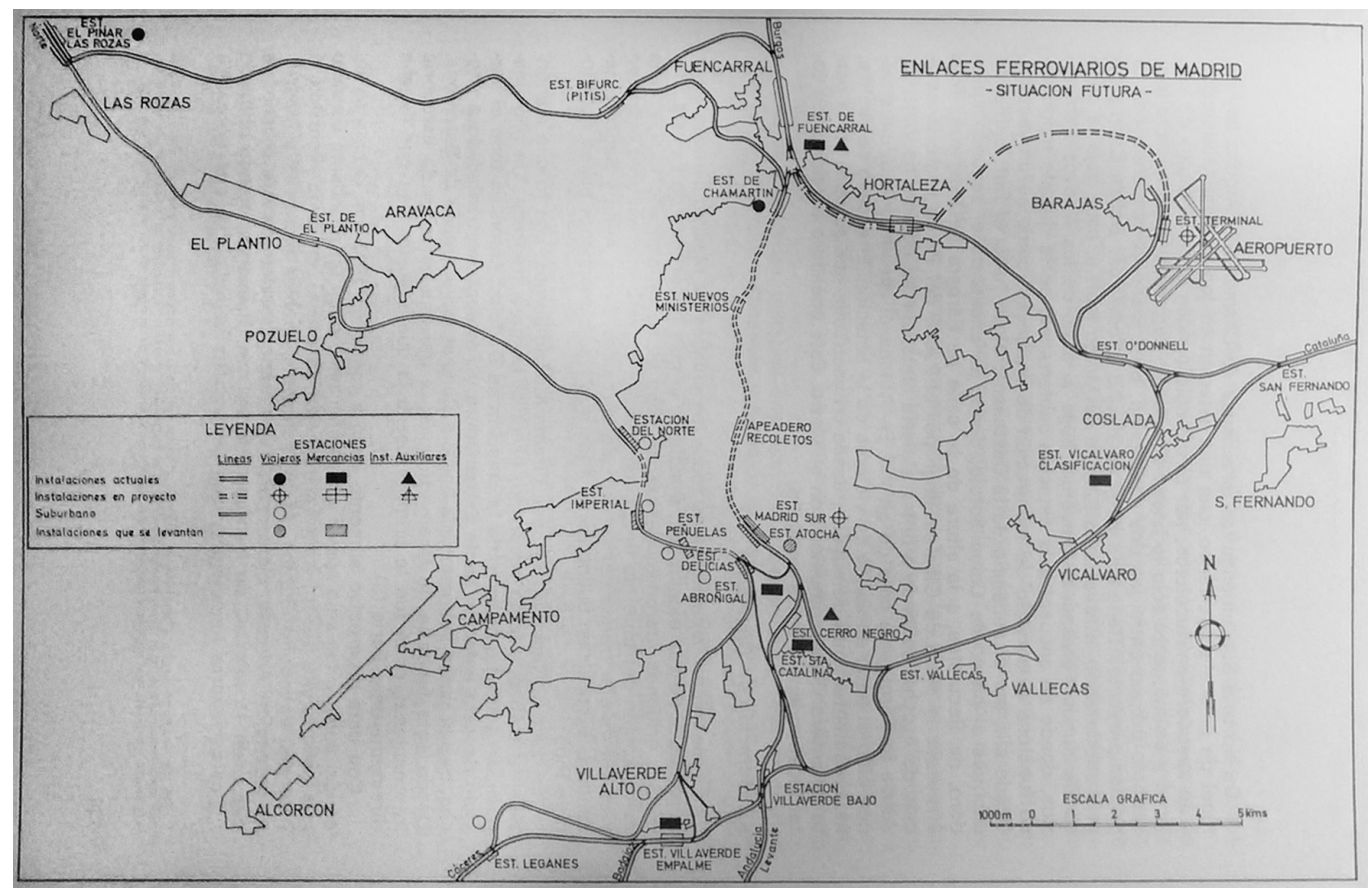

The goal is the study of the project actions which involve the railway station in its historical evolution, with the aim of identifying guidelines in historical established contexts. The historic reconstruction of urban areas through the relief and project design allows the knowledge and appreciation of the places by means of the representation of existing architecture and new proposals.

Historical drawings, projects presented in contests, graphic reliefs covering different periods and drawings for future proposals were analyzed in order to get critical knowledge of them. The multidisciplinary approach by means of architecture and urban planning is the basis of the identification of good practices of intervention in a stratified historical context; however, it requires contemporary interventions. The historical reconstruction of urban processes related to the field of infrastructure, understood in architectural perspective, highlights the elements of continuity and break in the history of transformation of places.

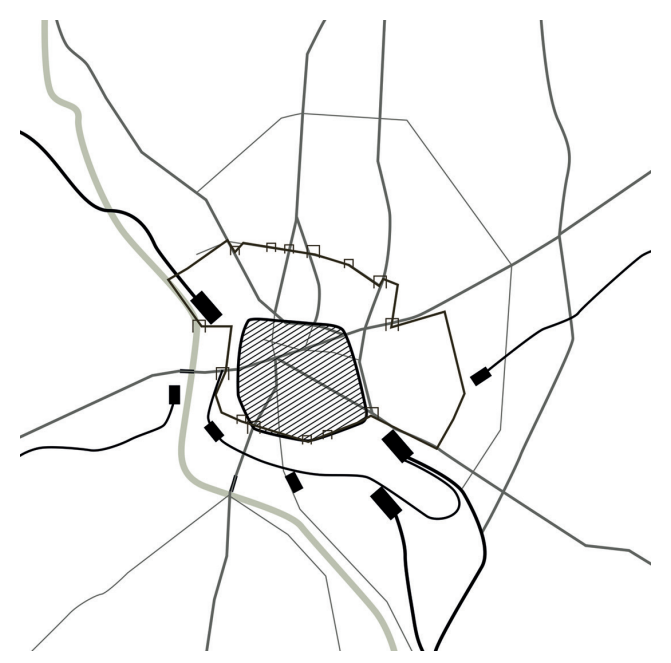


The reconstruction, by means of drawing, of the railway buildings in the various stages of development and the representation of those no longer existing, is an important asset to be used not only for cognitive purposes, but also as a starting point to plan new interventions. The railway buildings are emblematic places of the transition between tradition and innovation, bridging the nineteenth century and the contemporary era, in most cases persisting to transformations and adapting themselves to new needs. They perform both a role linked to their infrastructural function and are part of the architectural, urban and cultural heritage of a society, which identifies them as symbols of a place. For these reasons, they are not only architectures to be preserved, but to be studied and appreciated. Through the critical analysis and the historical reconstruction, we can design future transformations, based on a critical reasoning, operated starting from the knowledge of the history of the places. The guidelines, as identified according to this type of analysis, can be adopted to operate in other similar contexts from the point of view of the historical-cultural value of the places.

\section{References}

Aguilar Civera Inmaculada (1980). Las estaciones ferroviarias de Madrid: su arquitectura e incidencia en el desarrollo de la ciudad. Madrid: Colegio Oficial de Arquitectos de Madrid.

Aguilar Civera Inmaculada (1988). La estación de ferrocarril, puerta de la ciudad. Valencia: Generalitat Valenciana, Consellería de Cultura, Educación i Ciència.

González Yancí Maria Pilar (1977). Los accesos ferroviarios a Madrid: su impacto en la geografía urbana de la ciudad. Madrid: Instituto de Estudios Madrileños.

Navascués Palacio Pedro (1973). Arquitectura y arquitectos madrileños del siglo XIX. Madrid: Instituto de Estudios Madrileños.

Navascués Palacio Pedro (2007). Arquitectura e ingeniería del hierro en España, ( 8 | 4-1 936). Madrid: Fundación Iberdrola.

\footnotetext{
Author

Letizia Musaio Somma, Università degli Studi della Basilicata, letiziamusaiosomma@gmail.com

To cite this chapter. Musaio Somma Letizia (2020). L'architettura ferroviaria e le trasformazioni urbane: il caso di Madrid/Railway Architecture and Urban Transformation: the Case of Madrid. In Arena A., Arena M., Brandolino R.G., Colistra D., Ginex G., Mediati D., Nucifora S., Raffa P. (a cura di). Connettere. Un disegno per annodare e tessere. Atti del $42^{\circ}$ Convegno Internazionale dei Docenti delle Discipline della Rappresentazione/
Connecting. Drawing for weaving relationships. Proceedings of the 42 th International Conference of Representation Disciplines Teachers. Milano: FrancoAngeli, pp. 2477-2492.
} 